\title{
PENGETAHUAN BANTUAN HIDUP DASAR DAN KETERAMPILAN TINDAKAN RECOVERY POSITION PADA KADER SIAGA BENCANA
}

\author{
Trinurhilawati $^{1}$, Martiningsih ${ }^{2}$, Rini Hendari ${ }^{3}$, Ade Wulandari ${ }^{4}$ \\ 1,2,3,4 Jurusan Keperawatan, Poltekkes Kemenkes Mataram, Indonesia
}

\begin{abstract}
Abstrak
Menghadapi kondisi kegawatdaruratan seperti saat terjadinya bencana alam, menuntut individu dan kader yang menemukan korban untuk memberikan pertolongan segera. Penolong diharapkan memiliki pengetahuan serta keterampilan dalam memberikan bantuan hidup dasar, utamanya kader Tim Siaga Bencana kelurahan/TSBK yang telah mendapatkan pelatihan dan simulasi manajemen disaster dan bantuan hidup dasar. Namun kegiatan yang telah dilaksanakan belum dievaluasi tentang pengetahuan serta keterampilan dalam tindakan recovery position. Adapun tujuan dari penelitian ini adalah untuk menganalisis hubungan pengetahuan bantuan hidup dasar de ngan keterampilan dalam tindakan recovery position pada kader TSBK di Kota Bima. Dalam penelitian ini menggunakan desain cross sectional. Tekhnik pengambilan sampel yang digunakan adalah cluster sampling dengan jumlah sampel 38 responden. Pengambilan data menggunakan kuesioner dan lembar observasi. Hasil uji statistik Spearman Rank menunjukan nilai signifikansi ( $p$ value 0,000 ), $\alpha=$ 0,05 dengan nilai $r=0,614$, maka dapat disimpulkan terdapat hubungan yang kuat dan signifikan antara pengetahuan bantuan hidup dasar dengan keterampilan dalam tindakan recovery position pada kader TSBK di Kota Bima. Penelitian lebih lanjut perlu dilakukan untuk mengetahui peran kader dalam masyarakat setelah terjadinya bencana alam.
\end{abstract}

\section{Kata Kunci : Pengetahuan, Bantuan hidup dasar, Keterampilan, Recovery position}

\section{KNOWLEDGE OF BASIC LIFE SUPPORT AND SKILLS OF POSITION RECOVERY POSITION IN DISASTER ALERT}

\begin{abstract}
Emergency conditions such as during natural disasters, demanding individuals and cadres who find victims to provide immediate assistance. Helpers are expected to have the knowledge and skills to provide basic life support, especially cadres of the Village / TSBK Disaster Alert Team who have received disaster management training and disaster simulation and basic life Support. However, activities that have been carried out have not been evaluated regarding knowledge and skills in recovery position actions. The purpose of this study was to analyze the relationship of basic life assistance knowledge with skills in recovery position actions to TSBK cadres in Bima City. In this study using a cross sectional design. The sampling technique used was cluster sampling with a sample of 38 respondents. Retrieving data using questionnaires and observation sheets. The Spearman Rank statistical test results showed a significance value ( $p$ value 0,000 ), $\alpha=0.05$ with a value of $r=0.614$, it can be concluded that there is a strong and significant relationship between basic life assistance knowledge and skills in recovery position actions in TSBK cadres in the City Bima. Further research needs to be done to find out the role of cadres in the community after natural disasters.
\end{abstract}

Keywords: Knowledge, Basic life support, Skills, Recovery position 


\section{PENDAHULUAN}

Pengetahuan tentang bantuan hidup dasar (BHD) atau Basic Life support (BLS) sangat penting bagi masyarakat awam karena kejadian kegawatdaruratan dapat di jumpai dimana saja dan kapan saja. Sehingga dapat menjadi bekal untuk menolong orang lain. Bantuan hidup dasar merupakan tindakan yang bertujuan untuk mengembalikan dan mempertahankan fungsi organ vital pada korban henti jantung dan henti napas dengan memberikan kompresi dada atau resusitasi jantung paru dan pemberian napas bantuan. (Hardisman, 2014).

Dalam menghadapi kondisi kegawatdaruratan seperti saat terjadinya bencana alam menuntut individu atau kelompok yang menemukan korban untuk memberikan pertolongan segera. Akan tetapi, jika penolong tidak mengetahui cara yang baik dan benar dalam memberikan bantuan hidup dasar maka bisa berakibat fatal pada korban. Karena, lebih baik mengetahui pertolongan pertama dan tidak memerlukannya daripada memerlukan pertolongan pertama tetapi tidak mengetahuinya. Menurut Sjamsuhidajat (2004) dalam Turambi, Kiling, \& Supit (2016), penanganan korban di tempat kejadian merupakan hal yang sangat penting. Sebab, setiap kali kejadian bencana, petugas kesehatan sering kali datang terlambat ke lokasi bencana sehingga menyebabkan korban meninggal tanpa adanya tindakan pertolongan pertama.

Berdasarkan data WHO (World Health Organizasition) dalam Supriyantoro 2011, pada tahun 2005 terdapat 57,03 juta orang meninggal di seluruh dunia. Sekitar 35.000 - 50.000 diantaranya karena kecelakaan dan bencana alam yang diakibatkan oleh henti napas dan henti jantung. Dalam jumlah korban, Indonesia menempati peringkat kedua dunia, yaitu sebanyak lebih kurang 227.898 jiwa. Bencana alam di Indonesia mengakibatkan kerugian yang sangat besar, baik dari segi materi maupun jumlah korban (meninggal, luka - luka, maupun cacat). Korban meninggal umum disebabkan gagalnya oksigenasi adekuat pada organ vital (ventilasi tidak adekuat, gangguan oksigenisasi dan gangguan sirkulasi), cedera SSP masif (mengakibatkan ventilasi yang tidak adekuat dan/ atau rusaknya pusat regulasi batang otak), atau keduanya (Supriyantoro, 2011).

Sementara itu di tingkat propinsi, NTB menempati urutan ke-11 dari 28 wilayah di Indonesia yang rawan terjadi bencana gempa bumi dan tsunami. Sedangkan untuk wilayah Kota Bima berdasarkan data dari BPBD Kota Bima, sepanjang tahun 2016 lebih dari 40 kasus bencana alam salah satunya bencana banjir yang frekuensi kejadiannya lebih tinggi daripada kejadian bencana lain, yaitu sebanyak 12 kali dan berdampak pada $66 \%$ penduduk atau sebanyak 105.754 jiwa dari 159.736 jiwa jumlah penduduk Kota Bima.

Mencermati hal tersebut, BPBD Kota Bima dan HIPGABI Kota Bima telah memberikan pelatihan penanggulangan bencana dan Bantuan hidup dasar pada tanggal yang telah di ikuti oleh kader TSBK (Tim Siaga Bencana Kelurahan). Pengetahuan dan keterampilan BHD menjadi penting karena didalamnya diajarkan tentang bagaimana teknik dasar penyelamatan korban dari berbagai kecelakaan atau musibah sehari-hari yang biasa dijumpai (Fajarwati, 2012). Dengan kesiapsiagaan 
yang tepat berupa pelatihan kader dalam pemberian bantuan hidup dasar diharapkan upaya penanggulangan dapat lebih cepat dan tepat sehingga dapat meminimalisir jumlah korban dan kerusakan. Sebab, di tangan mereka terletak keberhasilan pengembangan dan pembinaan peran serta masyarakat sangat penting yang bertujuan agar terciptanya derajat kesehatan masyarakat yang optimal. Namun, Sejauh ini pemahaman, pengetahuan, dan kesiapan kader dalam memberikan bantuan hidup dasar dalam menghadapi situasi kegawatdaruratan belum ada data yang jelas. Sebab, kegiatan yang telah dilaksanakan belum dievaluasi pengetahuan serta keterampilan BHD maupun recovery position dan belum diketahui bagaimana peran kader dalam masyarakat setelah terjadinya bencana alam. Tujuan Penelitian ini adalah untuk meneliti hubungan pengetahuan bantuan hidup dasar dengan keterampilan dalam tindakan recovery position pada kader TSBK di Kota Bima tahun 2017

\section{METODE}

Desain penelitian yang digunakan adalah deskriptif analitik dengan rancangan cross sectional. Pengambilan sampel dengan metode cluster sampling dengan jumlah sampel 38 responden, pada responden yang memenuhi kriteria inklusi: Kader yang telah mengikuti pelatihan BHD, Bersedia secara sukarela untuk menjadi responden, Bisa membaca dan menulis dan kriteria eksklusi: Kader yang tidak berdomisili di Kelurahan tempat penelitian. Pengambilan data menggunakan kuesioner dan lembar observasi. Kuesioner pada penelitian ini terdiri dari dua bagian yaitu bagian (A) berisi karakteristik responden dan bagian (B) berisi pernyataan tentang bantuan hidup dasar pada masyarakat awam (lay person) menurut American Heart Association 2010. Kuesioner yang digunakan telah dkembangkan oleh (Rachmawaty, 2012). Responden menjawab kuesioner dengan memilih salah satu dari pilihan jawaban "Ya" atau "Tidak." Pemberian skor menggunakan skala Guttman : Benar $=1$, Salah $=0$ dengan kategori berpengetahuan baik, cukup dan kurang. Lembar observasi untuk mengidentifikasi ketrampilan responden dalam tindakan recovery position menggunakan SOP berdasarkan National Health Service dengan kategori terampil dan kurang terampil dengan menggunakan skala Guttmann, jika melakukan tindakan dinilai 1 dengan bobot yang tersedia pada lembar observasi check list dan jika tidak melakukan dinilai 0. Penelitian ini telah dilaksanakan mulai tanggal 01 Juni 2017 sampai dengan tanggal 14 Juni 2017 di wilayah Kelurahan Penato'i, Kelurahan Pane dan Kelurahan Dara. Analisis Data dengan uji parametrik Spearmen menggunakan SPSS 16.

\section{HASIL PENELITIAN DAN PEMBAHASAN}

Hasil Penelitian ini menjelaskan karakteristik responden dan data khusus pengetahuan, ketrampilan dan korelasi pengetahuan tentang BHD dan ketrampilan Recovery Position. Hasil dapat dilihat pada Tabel berikut: 
Tabel 1. Distribusi Frekuensi Responden Berdasarkan Usia, Jenis Kelamin, Pendidikan dan Pekerjaan $(\mathrm{n}=38)$

\begin{tabular}{clcc}
\hline No & Kategori Usia & n & Persentase (\%) \\
\hline 1 & Usia 20 - 30 tahun & 20 & 52.6 \\
\hline 2 & Usia $31-40$ tahun & 17 & 44.8 \\
\hline 3 & Usia $\geq 41$ tahun & 1 & 2.6 \\
\hline & Jenis Kelamin & & \\
\hline 1 & Laki-laki & 28 & 73.7 \\
\hline 2 & Perempuan & 10 & 26.3 \\
\hline & Tingkat Pendidikan & & \\
\hline 1 & SD/Sederajat & 0 & 0 \\
\hline 2 & SMP/Sederajat & 0 & 0 \\
\hline 3 & SMA/Sederajat & 24 & 63.2 \\
\hline 4 & Perguruan tinggi & 14 & 36.8 \\
\hline$\quad$ Pekerjaan & & 0 \\
\hline 1 & Petani & 0 & 2.6 \\
\hline 2 & Guru & 1 & 31.6 \\
\hline 3 & Wiraswata & 12 & 10.5 \\
\hline 4 & IRT & 4 & 23.7 \\
\hline 5 & Mahasiswa & 9 & 31.6 \\
\hline 6 & Lain-lain & 12 & $\mathbf{1 0 0}$ \\
\hline & Total & $\mathbf{3 8}$ & \\
\hline
\end{tabular}

Berdasarkan tabel diatas dapat diketahui bahwa dari 38 responden mayoritas berada pada kelompok usia 20-30 tahun (52,6\%), jenis kelamin laki-laki (73,7\%), tingkat pendidikan SMA $(63,2 \%)$ dan bekerja sebagai wiraswasta/Lain-Lain yaitu sebanyak 12 orang (31.6\%).

Tabel 2. Distribusi Frekuensi Responden Berdasarkan Pengetahuan Bantuan Hidup Dasar

\begin{tabular}{cccc}
\hline No & Pengetahuan & n & Persentase (\%) \\
\hline 1 & Baik & 28 & 73.7 \\
\hline 2 & Cukup & 10 & 26.3 \\
\hline 3 & Kurang & 0 & 0 \\
\hline & Total & 38 & 100 \\
\hline
\end{tabular}

Tabel 2 diatas menggambarkan bahwa sebagian besar responden mempunyai pengetahuan yang baik yaitu sebanyak 28 orang $(73.3 \%)$ dan yang berpengetahuan cukup sebanyak 10 orang (26.3\%). Hal ini dapat dikaitkan dengan faktor-faktor yang dapat mempengaruhi pengetahuan menurut pendapat Wawan \& Dewi (2011) yaitu tingkat pendidikan, informasi/media massa, social budaya dan ekonomi, lingkungan, pengalaman dan usia.

Sebagian besar usia responden berada pada usia dewasa awal yaitu usia 20-30 tahun sebanyak 20 orang $(52,6 \%)$ dan usia 31-40 tahun yaitu berjumlah 17 orang $(44,8 \%)$ dan usia $>41$ tahun berjumlah 1 orang (2,6\%). Menurut WHO umur dalam rentang 20-40 tahun disebut sebagai dewasa awal atau muda, 41-65 tahun sebagai dewasa tengah dan $>65$ tahun sebagai dewasa akhir (Erawati, 
2015). Berdasarkan uraian tersebut terdapat beberapa hal yang mendasari mayoritas responden adalah usia dewasa awal. Dilihat dari aspek intelektual usia dewasa awal memiliki kapasitas intelektual yang baik sehingga cenderung aktif untuk menambah pengetahuan yang mereka miliki dan dari aspek sosial usia dewasa awal aktif bersosialisasi sehingga ketika peneliti meminta bantuan untuk penelitian ini, orang yang dewasa awal lebih antusias. Disebabkan usia dewasa akhir tuntutan kognitif dari kehidupan adalah waktu untuk memperluas tanggung jawab pada pekerjaan, kehidupan di masyarakat, dan di rumah.

Selain itu, tingkat pengetahuan juga dapat dikaitkan dengan tingkat pendidikan responden yang rata-rata tingkat pendidikannya adalah SMA yaitu sebanyak 24 orang $(63,2 \%)$ dan perguruan tinggi berjumlah 14 orang $(36,8 \%)$. Di samping itu, bahwa semakin tinggi tingkat pendidikan seseorang maka semakin tinggi pula pemahaman dan pengetahuan orang tersebut.

Hal ini sejalan dengan penelitian yang telah dilakukan oleh Susi Erawati (2015) bahwa tingkat pengetahuan masyarakat di Jakarta Selatan tentang bantuan hidup dasar secara umum baik $(52,8 \%)$ dan berdasarkan tingkat pendidikan responden didapatkan bahwa mayoritas lulusan SMA yaitu sebanyak 136 orang $(55,3 \%)$ dan lulusan perguruan tinggi sebanyak 43 orang (17,5\%), lulusan SMP sebanyak 39 orang $(15,9 \%)$, lulusan SD sebanyak 27 orang $(11 \%)$ dan tidak sekolah sebanyak 1 orang $(0,4 \%)$.

Selain itu, pelatihan yang telah diikuti oleh semua responden dapat mempengaruhi pengetahuan responden tentang BHD. Hal ini didukung oleh pendapat Wawan dan Dewi (2011) bahwa pelatihan adalah salah satu bagian dari pendidikan non formal untuk dapat menemukan pengetahuan. Seseorang yang mendapatkan pelatihan berarti akan mendapatkan pengalaman terkait dengan pengetahuan yang didapatkan dari pelatihan. Pengalaman dapat berkaitan dengan umur dan pendidikan seperti pendidikan yang tinggi akan memiliki pengalaman lebih luas dan semakin berumur maka seseorang juga memiliki pengalaman yang semakin

Tabel 3. Distribusi Frekuensi Responden Berdasarkan Keterampilan Dalam Tindakan Recovery Position

\begin{tabular}{cccc}
\hline No. & Keterampilan & $\mathrm{n}$ & Persentase (\%) \\
\hline 1 & Terampil & 22 & 57.9 \\
\hline 2 & Cukup terampil & 14 & 36.8 \\
\hline 3 & Kurang terampil & 2 & 5.3 \\
\hline & Total & 38 & 100 \\
\hline
\end{tabular}

Hasil penelitian didapatkan bahwa dari 38 responden mayoritas responden terampil dalam tindakan posisi pemulihan yaitu sebanyak 22 orang (57.9\%), cukup terampil yaitu sebanyak 14 orang (36.8\%) dan kurang terampil berjumlah 2 orang $(5.3 \%)$.

Hal tersebut tidak terlepas dari adanya kegiatan pelatihan BHD yang sudah diikuti oleh semua responden. Dalam penelitian keterampilan ini rata-rata responden mampu melakukan sebagian 
maupun semua tindakan yang sudah ada di SOP mengenai recovery position. Selain itu, penelitian yang telah dilakukan oleh peneliti bahwa mayoritas responden memiliki pengetahuan yang baik yaitu sebanyak 28 orang $(73,7 \%)$ dan berpengetahuan cukup berjumlah 10 orang $(26,3 \%)$.

Hal ini didukung oleh pendapat Bertnus (2009) bahwa faktor - faktor yang dapat mempengaruhi keterampilan yaitu pengetahuan, pengalaman, keinginan/motivasi. Seorang individu harus memiliki faktor-faktor tertentu yang dapat mempengaruhi keterampilan, hal ini berkaitan dengan tindakan-tindakan yang harus dilakukan untuk membangun suatu keterampilan yang baik. Keterampilan tersebut bisa didapatkan dari pendidikan dan pelatihan. Keterampilan tersebut harus selalu ditingkatkan/dikembangkan dan dipelihara sehingga masyarakat yang sudah mengikuti pelatihan dan sudah terampil dapat menolong orang yang henti jantung dan henti napas.

Hasil penelitian yang dilakukan oleh Chaundary, Parikh, dan Dave (2011) yang menjelaskan bahwa terjadi peningkatan keterampilan RJP dapat dilakukan dengan cara mengikuti pelatihan BHD. Pelatihan yang berkesinambungan diperlukan untuk menyegarkan kembali pengetahuan dan keterampilan. Keenan, Lamacraft, dan Joubert (2009) menjelaskan bahwa penyegaran pelatihan harus dilakukan setiap 6-12 bulan untuk mempertahankan kemampuan skill BHD, hal ini disebabkan karena keterampilan seseorang tentang BHD khususnya RJP dapat menurun setelah 2 minggu dilakukan pelatihan, dan hasil penelitian lain yang dilakukan oleh Kuhnighk (2005) tentang keterampilan dan penilaian diri dalam resusitasi jantung paru dari pegawai rumah sakit, didapatkan hasil penelitian menunjukkan 36\% pegawai rumah sakit berketerampilan cukup dari 425 responden.

Tabel 4. Tabulasi Silang Hasil Pengukuran Pengetahuan Bantuan Hidup Dasar Dengan Keterampilan Dalam Tindakan Recovery Position

\begin{tabular}{|c|c|c|c|c|c|c|c|c|c|}
\hline \multirow[t]{3}{*}{ No } & \multirow[t]{3}{*}{ Pengetahuan } & \multicolumn{6}{|c|}{ Keterampilan } & \multicolumn{2}{|c|}{ Jumlah } \\
\hline & & \multicolumn{2}{|c|}{ Terampil } & \multicolumn{2}{|c|}{$\begin{array}{c}\text { Cukup } \\
\text { terampil }\end{array}$} & \multicolumn{2}{|c|}{$\begin{array}{l}\text { Kurang } \\
\text { terampil }\end{array}$} & \multirow[b]{2}{*}{$\mathbf{n}$} & \multirow[b]{2}{*}{$\%$} \\
\hline & & $\mathbf{n}$ & $\%$ & $\mathbf{n}$ & $\%$ & n & $\%$ & & \\
\hline 1 & Baik & 21 & 55.3 & 7 & 18.4 & 0 & 0 & 28 & 73.7 \\
\hline 2 & Cukup & 1 & 2.6 & 7 & 18.4 & 2 & 5.3 & 10 & 26.3 \\
\hline \multirow[t]{3}{*}{3} & Kurang & 0 & 0 & 0 & 0 & 0 & 0 & 0 & 0 \\
\hline & Jumlah & 22 & 57.9 & 14 & 36.8 & 2 & 5.3 & 38 & 100 \\
\hline & \multicolumn{3}{|c|}{ Uji Statistik Spearman } & \multicolumn{2}{|c|}{$p=0,000$} & \multicolumn{3}{|c|}{$r=0,614$} & \\
\hline
\end{tabular}

Berdasarkan data tabulasi silang antara pengetahuan bantuan hidup dasar dengan keterampilan dalam tindakan recovery position diperoleh hasil dari responden yang berjumlah 38 orang yaitu responden yang memiliki pengetahuan baik dan terampil sebanyak 21 orang (55.3\%), sedangkan responden yang berpengetahuan cukup dan cukup terampil berjumlah 7 orang (18.4\%).

Pengetahuan yang dimiliki kader tentang BHD sangatlah berpengaruh pada keterampilan dalam melakukan tindakan recovery position dilihat dari banyaknya responden yang berpengetahuan baik dan terampil. Hal ini didukung oleh teori yang dikemukakan oleh Cristian (2009) bahwa pengetahuan yang baik sangat berpengaruh pada keterampilan yang baik pula, keterampilan atau 
kemampuan seseorang menerapkan pengetahuan yang dimiliki ke dalam bentuk tindakan dimana seorang individu yang menemukan korban yang henti jantung dan henti napas dapat melakukan BHD dengan memberikan RJP dan melakukan tindakan posisi pemulihan saat korban sudah ada denyut nadi dan napas sehingga mencegah terjadinya obstruksi jalan napas.

Responden yang berpengetahuan baik dan cukup terampil berjumlah 7 orang (18.4\%), responden berpengetahuan cukup dan terampil sebanyak 1 orang $(2.6 \%)$ dan responden yang berpengetahuan cukup dan berketerampilan kurang sebanyak 2 orang (5.3\%). Hal ini menunjukan keterampilan tidak selalu dipengaruhi oleh pengetahuan, keterampilan juga bisa dipengaruhi oleh pendidikan, pengalaman, pelatihan, keinginan/motivasi. Pelatihan yang berkesinambungan diperlukan untuk menyegarkan kembali pengetahuan dan keterampilan. Keenan, Lamacraft, dan Joubert (2009) menjelaskan bahwa penyegaran pelatihan harus dilakukan setiap 6-12 bulan untuk mempertahankan kemampuan skill BHD, hal ini disebabkan karena keterampilan seseorang tentang BHD dapat menurun setelah 2 minggu dilakukan pelatihan.

Hasil Penelitian yang dilakukan oleh peneliti saat ini sejalan dengan penelitian Alhidayat, Rahmat dan Simunati (2013) dimana hasil penelitian tersebut menunjukkan tingkat pengetahuan perawat yang tinggi berpengaruh terhadap keterampilan atau pelaksanaan yang tinggi pula dengan nilai $p: 0,004$ sedangkan hasil penelitian yang telah dilakukan oleh peneliti sendiri menunjukan adanya hubungan pengetahuan responden yang baik dengan keterampilan yang tinggi dalam melakukan tindakan recovery position pada tingkat signifikan $\mathrm{p}=0.000$ lebih kecil dari alpha : 0,05 dan nilai koefisien korelasi $=0.614$ yang menunjukkan kuatnya hubungan antara dua variabel .

\section{KESIMPULAN}

Pengetahuan responden tentang bantuan hidup dasar sebagian besar berpengetahuan baik dan Mayoritas keterampilan responden dalam tindakan recovery position adalah kategori terampil serta terdapat hubungan yang kuat dan signifikan antara pengetahuan bantuan hidup dasar dengan keterampilan recovery position.

\section{DAFTAR PUSTAKA}

Alhidayat, N,A., Rahmat, A., Simunati. (2013). Hubungan Tingkat Pengetahuan Perawat Instalasi Gawat Darurat tentang Pengkajian terhadap Pelaksanaan Tindakan Life Support di Rumah Sakit Pelamonia Makassar. Vol. 2, No. 4

Alimul, A. H. (2007). Metode Penelitian Kebidanan dan Tekhnis Analisis Data. Jakarta: Salemba Medika.

American Heart Association (AHA) (2005). Basic Life Support Health Care Provider Pre-test. (sitase) http://www.clinicalnursinginstitue.org pada tanggal 19 Januari 2017 jam 12.30 WITA

American Heart Association (AHA) (2010). Basic Life Support: Guidelines for cardiopulmonary Resucitation and Emergency Cardiovaskuler Care, (sitase) http://circ.ahajournals.org tanggal 19 Januari 2017 jam 12.43 WITA 
American Heart Association (2011). CPR \& Sudden Cardiac Arrest (SCA) Fact Sheet, CPR Statistics. (sitase) http://www.heart.org pada tanggal 19 Januari 2017 jam 12.47 WITA

American Heart Association (2015). Fokus Utama Pembaruan Pedoman American Heart 2015 untuk CPR dan ECC. (sitase)

http://www.eccguidelines.heart.org pada tanggal 26 Januari 2017 jam 14.15 WITA

Arikunto, Suharsimi. (2013). Prosedur Penelitian: Suatu Pendekatan Praktik cet.15.Jakarta: Rineka Cipta

Bagian Pendidikan Dan Penelitian. (2016). Materi Pelatihan Basic Life Support. Denpasar : RSUP Sanglah Denpasar

Berg RA, Hemphill R, Abella BS, Aufderheide TP, Cave DM, Hazinski MF, Lerner EB, Rea TD, Sayre MR, Swor RA (2010). Part 5: Adult basic life support: American Heart Association Guidelines for Cardiopulmonary Resuscitation and Emergency Cardiovascular Care Circulation ; 122 (suppl3) : S685-S705.

Bertnus. (2009). Faktor yang Mempengaruhi Keterampilan. (sitase) http://digilib.unimus.ac.id pada tanggal 16 Juni 2017

Cristian, W.G. (2009). American Journal of Respiratory and Critical Care Medicine. BMC Public Health

Erawati, S. (2015). Tingkat Pengetahuan Masyarakat Tentang Bantuan Hidup Dasar (BHD) Di Kota Administrasi Jakarta Selatan. Skripsi, Universitas Islam Negeri Sarif Hidayatullah , Program Studi Ilmu Keperawatan Fakultas Kedokteran Dan Ilmu Kesehatan, Jakarta.

Fajarwati, H. (2012). Basic Life Support tim bantuan medis FK UII. (Sitase) http://medicine.uii.ac.id tanggal 20 Juni 2017

Hardisman. (2014). Gawat Darurat Medis Praktik. Yogyakarta: Gosyen Publishing.

Rachmawaty, S. (2012). Gambaran Tingkat Pengetahuan Mahasiswa Kesehatan Dan Non-Kesehatan Universitas Indonesia Tentang Tekhnik Resusitasi Jantung Paru (RJP) Pada Orang Dewasa. Skripsi, Universitas Indonesia, Fakultas Ilmu Keperawatan Program Sarjana Reguler, Jakarta.

Supriyantoro. (2011). Kebijakan Kemenkes dalam Sistem Penanggulangan Gawat Darurat Terpadu (SPGDT) dan Bencana.

Turambi, D. E., Kiling, M., \& Supit, D. (2016, Juni). Pengaruh Pelatihan Bantuan Hidup Dasar (BHD) Terhadap Peningkatan Pengetahuan dan Ketrampilan Siswa Kelas XI dan XII SMA Negeri 2 Langowan. Buletin Sariputra, VI (2), 1-8.

Wawan A \& Dewi M. (2011). Teori dan Pengukuran Pengetahuan, Sikap dan Perilaku. Yogyakarta: Muha Medika. 